\title{
Renovações
}

\author{
Harley E.A. Bicas
}

Em uma reunião do corpo editorial dos Arquivos Brasileiros de Oftalmologia em agosto de 2005, poucos dias antes do que se aproximava como o de assunção da Presidência do Conselho Brasileiro de Oftalmologia, comuniquei aos seis Editores Associados minha resolução de deixar o cargo de Editor Chefe da revista. O assunto já foi comentado no editorial "Transição", aparecido no último número do volume 68 (ano de 2005): após emocionantes manifestações de carinho desses queridos amigos, concordei com a proposta que me faziam de me manter formalmente na responsabilidade do cargo, embora, na prática, se lhes a transmitisse.

Durante estes dois anos acompanhei a revista de um modo duplamente orgulhoso: como Presidente do C.B.O., por poder contar com ela como expressão digna do que se faz em ciência e prática de nossa madura e atualizada Oftalmologia; e como seu Editor Chefe, depositário da confiança daqueles seis, eles sim os verdadeiros artífices das publicações. Raras vezes fui chamado a intervir, sobre alguns assuntos de maior dificuldade; e, mesmo então, apenas para confirmar o que já se delineava como solução proposta pelo grupo. O que, sobretudo, confirmava minha certeza de que a capacidade científica e gerencial desse conjunto dos Editores Associados e de cada um deles em particular, dispensava, efetivamente, a necessidade de minha pretensa liderança.

Por outro lado, é possível que haja sido exatamente essa homogeneidade e pujança dos valores coletivos desse seletíssimo grupo e, principalmente, a ética e o respeito mútuo de cada um de seus componentes, a razão determinante de eles terem preferido evitar o surgimento de hegemonias individuais, para sobrelevar o necessário serviço da equipe. É mais uma reverência que se deve fazer a essas notabilíssimas pessoas: sobre a excelência do trabalho, o modo elegante como o desempenharam.

Mas, à medida que o tempo fluía, mudanças de perspectivas foram ocorrendo a esses colaboradores, determinando que alterações de suas atividades lhes surgissem como mais convenientes. Assim, por exemplo, Samir, Goldchmit e Vital solicitaram dispensas de suas funções como Editores Associados, mantendo-se, entretanto, em seus postos até agora, em gentilíssima deferência a pedido especial que lhes fiz para continuarem colaborando com a revista até o final de 2007.

Samir Jacob Bechara exerce essa função desde janeiro de 1998. É um longo tempo de serviços prestados aos Arquivos Brasileiros de Oftalmologia. Samir, entre tantas outras muitas ocasiões, terá sua falta sentida principalmente naquelas em que estiverem envolvidas questões de ética e de Direito. (Para quem ainda não sabe, ele também se graduou pela Faculdade de Direito do Largo São Francisco - USP). Farão falta suas sábias e lúcidas ponderações sobre os mais variados temas.

Vital Paulino Costa, também nos Arquivos desde janeiro de 1998 não deixa de participar desse tipo de trabalho editorial, por aceitar convite do British Journal of Ophthalmology, o que honra a nossa Oftalmologia. Certamente lá continuará a mostrar sua marca de objetividade e rigor em suas análises críticas, uma invejável garantia de qualificação no aproveitamento dos artigos recebidos para publicação.

Mauro Goldchmit, servindo aos Arquivos há "apenas" 8 anos, lega-nos não somente a capacidade crítica e o alto nível de suas revisões, mas brilhantes idéias que, postas em prática, tornaram-se rotinas na administração da revista. Um organizador primoroso, cuja presença sempre elevou a eficiência do grupo.

Permanecem conosco Cristina Muccioli, agora incumbida, especificamente, de intensificar a divulgação da revista, expandindo a leitura de suas matérias, por meio de publicação de artigos de revisão e, ou, metanálises propostos a eminentes nomes do cenário internacional. O que deve servir para aumentar nosso "fator de impacto", gerar intercâmbios e mais conhecimento sobre a Oftalmologia aqui realizada. Paulo Elias Correa Dantas ficará com a gerência dos meios eletrônicos de produção dos Arquivos (programas de interação da revista com seus autores e analistas, ABOONLINE) e de sua publicação (ABONET), mecanismos de facilitação de buscas e de interrelações de matérias. Mauro Silveira de Queiroz Campos supervisionará a distribuição de artigos para análises, pelos novos Editores Associados e o fluxo com que elas se processam, objetivando abreviar o período decorrido entre a recepção de um trabalho e sua publicação.

O Conselho Administrativo dos Arquivos Brasileiros de Oftalmologia, reunindo-se pela primeira vez depois de sua consolidação formal nos instrumentos de gestão do C.B.O. (Regimento Interno e Estatuto) teve a oportunidade de escolher nomes para a composição de um novo corpo de Editores Associados, dos quais se esperará uma atuação mais direta e personalizada no exame da pertinência e qualidade de um trabalho enviado à revista.

Obviamente, por outro lado, seguem os Conselheiros Editoriais como elementos fundamentais de apoio à edição dos A.B.O. Nessa lista, algumas mudanças também ocorreram. Periódicas, são sempre convenientes e, por isso mesmo, substituições não devem ser interpretadas como relacionadas a reconhecimentos diminuídos de méritos pessoais dos que saem. Ao contrário, não é raro ser justamente a elevação do nível de ocupações, determinada pelo exercício profissional e, ou, aca- 
dêmico, a razão de os tempos das pessoas tornarem-se menos disponíveis para análises de estruturas, conteúdo e forma de um artigo científico. De qualquer modo, não há como explicitar novas oportunidades a um, sem que sucedam compreensivas e generosas aceitações de cessão por outros, cujas excelentes colaborações continuarão a ser indispensáveis.

Finalmente, não posso deixar de mencionar, além de toda essa equipe de valorosos elementos da ciência, o trabalho prestimoso do dia-a-dia de Claudete, Cláudia, Paulo Imamura,
Hanna, Edna e Maria Elisa, de Adamo (buscando patrocínios, pagando contas) e o apoio de Hamilton Moreira, Presidente do C.B.O. e de sua Diretoria. E, portanto, também com eles e por eles, os A.B.O. prosseguem em seus enfretamentos de novos desafios, com o entendimento de que seja elemento refletor do crescimento contínuo de nossa Oftalmologia e, ao mesmo tempo, fator com que ela se consolida no conceito internacional.

Novos tempos. Aceleremos!
XVIII CONGRESSO BRASILEIRO DE PREVENCAOO DA CEGUEIRA E -

F L O R I A N Ó P O L I S 03 A 06 DE SETEMBRO DE 2008 - CENTROSUL

\section{Congresso Brasileiro de Prevenção da Cegueira e Reabilitação Visual}

03 a 06 de setembro de 2008

Florianópolis - SC

\section{Último prazo para envio de trabalhos científicos (resumos): $17 / 03 / 2008$ \\ Só serão aceitos trabalhos enviados "online": www.cbo2008.com.br}

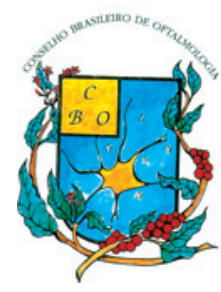

\section{Normas gerais para envio de temas livres e relatos de casos}

1. Os resumos devem ser inéditos, não publicados até a data de apresentação no congresso.

2. O CBO só aceita o envio digital. Resumos não devem ser enviados pelo correio. A data limite para envio será no dia 17/03/2008 às 24:00h.

3. Envios posteriores não serão aceitos, sem exceção de qualquer ordem.

4. Cada participante poderá ser primeiro autor de apenas um resumo.

5. Não há limites para quantas vezes o participante aparece como co-autor em resumos.

6. Não submeta um resumo se não for sua intenção comparecer ao congresso.

7. Os resumos a serem submetidos devem conter, no caso de aceite, o mesmo conteúdo do que será apresentado no congresso.
8. O CBO se reserva ao direito de recusar resumos segundo determinação dos avaliadores.

9. Não serão aceitos trabalhos de revisão de literatura.

10. 0 processo de avaliação é sigiloso e os avaliadores assinam termo que caracteriza a confidencialidade da mesma estando proibidos de se manifestar fora da comissão avaliadora.

11. Os autores que não puderem comparecer deverão solicitar por escrito ao CBO até o dia $\mathbf{3 0}$ de maio a retirada do envio. $O$ resumo em que o primeiro autor não esteja presente para apresentação (tanto oral quanto pôster), cuja falta não tenha sido justificada, será considerada falta grave e a instituição onde a pesquisa foi realizada será advertida oficialmente pelo CBO.

12. Interesses comerciais devem ser explicitados e declarados por todos os autores e co-autores. 